\title{
Language and Identity Development Among Syrian Adult Refugees in Canada: A Bourdieusian Analysis
}

\author{
Needal Ghadi \\ University of Regina \\ ghadi20n@uregina.ca \\ Christine Massing \\ University of Regina \\ Christine.Massing@uregina.ca \\ Daniel Kikulwe \\ University of Regina \\ Daniel.Kikulwe@uregina.ca \\ Crystal J. Giesbrecht \\ University of Regina \\ Crystal.Giesbrecht@uregina.ca
}

\begin{abstract}
Framed by Bourdieu's work, this article focuses on the intersections between language learning experiences, capital, and identities of Syrian refugees now living in Regina, Saskatchewan. In this qualitative study, data were collected during a series of focus groups with Syrian women and men. Based on the study findings, we contend that the participants' multiple identities as hardworking, employed, independent, Muslim mothers or fathers, and wives or husbands developed in Syria were gradually eroded or altered by the realities they experienced in Canada, yet they had a strong desire to re-establish their identity constructions from back home in the new context. We assert that the loss of their linguistic capital from back home limited their employment prospects, impacted their abilities to form social relationships with native English speakers, and led to a shift in traditional gender roles. It is imperative to adapt language training programs in order to support refugees in re-establishing themselves in their professional fields and daily living activities.
\end{abstract}

\section{Introduction}

The recent arrival of comparatively large numbers of Syrian refugees fleeing war and persecution has necessitated resettlement in smaller urban centres, such as Saskatoon and Regina, which have not typically received large numbers of newcomers (CIC, 2016). In 2016, for instance, Saskatchewan resettled a total of 1,320 Syrian refugees in a short period of time (CIC, 2017), many of whom came with a very limited ability to communicate in English or French, the dominant languages. According to numerous studies, learning a new language is one of the most challenging barriers for newcomers in terms of adapting to their new environment, finding employment, and integrating into the host society (Adamuti-Trache, 2012; Boyd \& Cao, 2009; Ostrovsky, 2008; Plante, 2011; Rudenko, 2012; Weiner, 2008). Despite such evidence, many 
newcomers are still unable to access language training programs that meet their goals and expectations for accessing employment and education (Sutherland, Wheller, \& Conrad, 2008) and allow them to experience one-on-one interactions with native speakers (Gotseva, 2015). Furthermore, such programs typically privilege English proficiency as the only means by which newcomers can access educational and occupational opportunities (Duran, 2016).

Framed by Bourdieu's concepts of capital and habitus, in this article we focus on the intersections between capital, language, and identity as related to Syrian men's and women's English language learning experiences. We examine how learning (or not learning) the dominant language can influence their identity development as well as facilitate or hinder their integration within Canadian society. More specifically, these participants came with identities as workers, parents, and Muslims constructed "back home" in Syria that they sought to re-establish in the Canadian context but found they could not do so without learning English. However, in the course of their studies, they perceived a mismatch between the goals of the language training program and their own goals. The loss of their linguistic capital from back home not only limited their employment prospects, placing them at an economic disadvantage but also impacted their abilities to form social relationships with native English speakers. Accordingly, we examine language as a form of social capital that provides its holders with significant economic and social opportunities and argue that learning the dominant language becomes a vital source for reshaping refugees' lives and reconstructing their identities.

\section{Bourdieu's Concepts of Capital and Habitus}

In conceptualizing the experience of adult Syrian refugees in Canada and their efforts to "embody" their places in their receiving country, we have drawn on the work of Bourdieu, and in particular his concepts of capital and habitus (Bourdieu, 1977; Bourdieu \& Wacquant 1992; Bourdieu, 1997). Applied together, these concepts offer a significant conceptual framework for understanding how the post-arrival life experiences of Syrian refugees is related to their everyday social interactions. Focusing on the state of transition, we specifically examine how learning the dominant language can facilitate the development of Syrian refugees' identities, as well as enrich their status in the host society. In Bourdieu's framework, the various forms of capital - economic, cultural, social and symbolic- are resources which individuals can draw upon to secure advantages in particular fields. Crucially, for the various forms of capital to be valued they must exist in a field or context in which they are recognized, appreciated and can be employed. Only when cultural and social capital have been recognized as legitimate can it be converted into symbolic capital which brings with it symbolic power.

The refugees in the present study have all come from social backgrounds where education and employment are highly valued. Their habitus - the embodied characters, expressed through ways of speaking, thinking and feeling - and the cultural and social capital acquired, have enabled them to move quite easily through education and into professional or skilled positions while in their country of origin. However, Bourdieu argues that when individuals encounter a new and unfamiliar field, habitus is recreated or at least transformed to meet the conditions under which the dominant social structures operate. While not easily altered, socialization and new experiences have a significant influence on the ways in which our habitus is being restructured within a new social world (Bourdieu, 1990). 


\section{Conceptualizing Language as Capital}

Bourdieu argues that language, as a practice, is not merely a method of communication, but also a mechanism of power that impacts individual's access to various social networks, their identities and their access to sources and forms of cultural knowledge (Bourdieu, 1977, 1991). His notion of "linguistic capital" refers to "the fluency in, and comfort with, a high status... language which is used by groups who possess economic, social and political power and status in local and global societies" (Morrison \& Lui, 2000, p. 473). Similar to other forms of capital, linguistic capital is unevenly distributed. As such, the different amounts of linguistic capital which speakers may own are the "retranslation of social differences" (Jenkins, 2002, p. 154). Thus, language becomes a site of symbolic struggle where social groups maneuver to impose their vision of social divisions as legitimate (Bourdieu, 1984). In the case of language learning, refugees who are unable to speak the dominant language, might be constructed as inferior to those who are fluent in the dominant language (Murray, 1998; Peirce, 1995). Even more, language learners may also be seen as outsiders who are to be excluded from taking an active role and having an influential voice in civil society (Berry \& Williams, 2004). Therefore, not possessing skills in the dominant language not only places some individuals in subject positions but also contributes to their isolation and marginalization.

As previously mentioned, learning and communicating in the receiving country's language is an essential source for becoming an active part of a society and accessing cultural, emotional and social resources (Gerhards, 2012). However, according to Bourdieu (1991), learning the dominant language is not only related to gaining social advantage, but also a vital resource for obtaining symbolic capital. Thus, symbolic capital is the acknowledgment of legitimate authority made available to an individual in a particular social context (Bourdieu, 1986). Although language acquisition provides one with a medium of communication and potential for symbolic capital, individuals can also be disadvantaged because of their other social identities, such as gender, class, race, ethnicity, abilities, religion, and so forth. However, we cannot ignore the relevance of symbolic capital, which is both a form of capital and embedded within the other forms of capital. As Gemme (2009) explains, “the symbolic capital plays a special role: one's reputation and the respect received from the community will influence the value of the other forms of capital held by a given agent" (p. 21). One important argument here is that refugees and other marginalized people are in constant search for respect and the need to 'fit in' within their new social worlds through creative linguistic practice. Consequently, newcomers who do not learn the language are faced with two possibilities - they can either accept the values, beliefs, perceptions, and decisions of the dominant symbolic order in society, which Bourdieu (1991) refers to as "symbolic violence," or they can work to change the existing symbolic order, for example, through confrontation or disorder (Hilgers \& Mangez, 2015). That is, newcomers may begin to challenge and question the unequal distributions of different kinds of capital to their benefit by suggesting unconventional notions about how to deal with political, social, and economic issues or by reorienting their day-to-day life practices to include adhering to or resisting the norms and conventions of the host country (Salö, 2017; De Clercq \& Voronov, 2009). For Syrian refugees, it's not only a matter of learning a new language and readapting to a completely new way of life but also having to deal with the idea that Islam usually goes against modernity. 


\section{Conceptualizing Language as Identity}

The study of language use and identity has shifted from a predominantly psycholinguistic approach to include greater sociological and cultural dimensions of learning a particular language (Morgan, 2007; Norton \& Toohey, 2011). Here, identity is seen as socially constituted, reflexive and a dynamic product of the social, historical and political contexts of an individual's lived experiences (Hall, 2012). In this sense, learning the dominant language becomes a vital source for reshaping refugees' lives and reconstructing their identities (Morrice, 2012; Norton \& Toohey, 2011). For Bourdieu (1991), language is a practice embedded in our habitus through which we as speakers become socially identifiable to others. This structural perspective indicates that individuals are a product of social structure or constructed by the social environment and that their identities are detected through the social positions they occupy within this structure (Eakin, 2008; Holmes, 1997; Bucholtz, 1999).

The importance of building social relationships (cultural capital) between 'native' and 'nonnative' speakers of the language is evident in Bourdieu's (1977) work as illustrated by the idea that "speech always owes a major part of its significance to the value of the person who utters it" (p. 652). This implies that a speaker wants not only to be understood but to be "believed, obeyed, respected, and distinguished" (Bourdieu, 1977, p. 648). Norton (2006) echoes Bourdieu's idea when she talks about the struggles faced by language learners when attempting to learn a second language in a social environment. She explains, "the value ascribed to speech cannot be understood apart from the person who speaks, and the person who speaks cannot be understood apart from larger networks of social relationships" (p. 25). Norton's remarks highlight the instability and constantly emerging nature of identity. As refugees, like others, progress in their daily lives, their sense of self is not only developing but rather colliding sometimes internally. Nunan and Choi (2010) capture such identity shifts and relate them to globalization and the large-scale migrations of people around the world. They point out that this has resulted in "the emergence of a more dynamic type of identity formation that confronts people with hybridized or cosmopolitan identities" (p. 3). Nevertheless, newcomers, especially refugees, usually do not have access to the various social and familial networks they were part of back home, at least upon arrival (George \& Chaze, 2009; Kunz, 2003). Refugees also arrive with perceptions, ideas, and beliefs that might not fit within their new society (Lichtenstein, Puma, Engelman, \& Miller, 2016; Sanders, Nee, \& Sernau, 2002), such as gender roles, child socialization goals, and social/religious practices. More importantly, refugees are considered to lack the required language abilities to participate in social interactions with individuals from the host country (Perrin \& Dunn, 2007). Additional elements such as racism and 'Islamophobia' may also prove to be hindrances, preventing refugees from forming social relationships with members of the dominant society even if language barriers can be surmounted (eg. Alshabibi, 2018). This lack of social relations prevents them from holding and retaining power and capital compared to dominant social groups. As a result, multiculturalism might become more incompatible, and racial ideologies more biased, towards those who are not 'similar' or do not speak the same language. 


\section{Gender Roles and Social Identities}

Linguistic performances also define gender roles within a social identity. For Bourdieu, social identity is primarily understood through gendered differences among agents, an understanding of the objective structures and cognitive structures, which are often hidden (Bourdieu, 2001). This implies that our social practices and positions are initially defined by our habitus and the "appropriate" roles and identities assigned to us by social norms. These norms, including the language(s) we speak, are produced via salient discourses, or particular "sets of ideas" that carry weight in society (Eckert \& McConnell-Ginet, 2003). In other words, social constructions define how masculinity and femininity are perceived, and thus define our identity. Bourdieu further argues that it is through the logic of the habitus that gender classifications are integrated, and it is also through the habitus that these classifications are kept alive (Krais, 2006). Yet, since identity is constructed by human beings, Bourdieu understands society and our social practices as being fluid and flexible to an extent that there would always be room for altering familiar attitudes and for engaging in symbolic struggle (Bourdieu, 2000, p. 234). Post-migration shifts in traditional gender roles can generate tensions within newcomer families. In the present study, we highlight Bourdieu's notion of socially constructed gender roles within the Syrian participants we interviewed and, especially, the women's reliance on their husbands as the main providers of the family before coming to Canada. The idea of acquiring independence and symbolic power through learning the dominant language has become an essential need for them to achieve recognition after arriving to Canada.

\section{Methodology}

The research presented here draws from data from two related projects. One of these projects was a large mixed-methods study, the purpose of which was to elucidate the barriers newcomers experienced in accessing employment, educational opportunities, and child care in the city of Regina, Saskatchewan (Kikulwe, Massing, Halabuza, Giesbrecht, \& Ghadi, 2017). Quantitative data were collected through questionnaires completed by community stakeholders working directly with newcomers $(n=194)$ and newcomers themselves $(n=305)$. Qualitative data were collected during 13 1/2-2-hour semi-structured focus groups with 96 newcomers recruited through snowball sampling. Two focus groups were with Syrian female and male participants respectively. For the second project, data were generated in four additional focus groups (two with men and two with women) aimed at understanding their language learning experiences in Regina. In the focus groups we used a semi-structured format with open-ended questions designed to stimulate discussion among participants by using leading questions (see Hesse-Biber \& Leavy, 2006; Wibeck, Dahlgren, \& Öberg, 2007). The participants were asked questions about their pre-migration, migration, and resettlement educational experiences, beginning with more general, grand tour questions (Spradley, 1979) and then moving into a series of probes to clarify or amplify their responses. The data for this paper draws from all six of these focus groups with Syrian refugees (25 men and 17 women). In the second project, we added questions intended to elicit their pre-migration experiences around the same topics and found comparable data across both projects.

Focus group participants were recruited both through immigrant-serving agencies and the connections one of the research team members had established through membership in the local 
mosque and participation in activities within the Syrian/Middle Eastern ethnocultural community in Regina. In order to participate in the study, the participants had to: 1) be of Syrian descent; 2) be a government-sponsored refugee; 3) be over the age of eighteen, and 4) reside in the City of Regina. All of the participants had been in Canada for less than two years. All of the participants were between the ages of 25 and 50, with the exception of one of the women and one of the men who were over the age of 50. Since many of the participants spoke Arabic but very little English, one team member provided interpretation during the focus groups with the men, transcribed/ translated all of the recordings, and translated the information letter and consent forms. A female interpreter assisted the female researchers with the three focus groups with Syrian women. To complete the data analysis, the research team completed multiple readings of the transcripts, developing a coding framework, as well as a pattern-level analysis to identify themes related to the participants identities. These themes provided insights into both the Syrians' educational experiences back home and in Regina as well as their efforts to seek employment in Regina. While the participants envisioned transferring or relocating their established identities from "back home" to the Canadian context, they lacked the appropriate linguistic capital to do so.

\section{Findings}

Analyses of the data allowed for the identification of four key identities in relation to language learning — being "hard-working," being a "worker," being a parent, and being a Muslim — as well as ways in which these identities shifted in the new context.

\section{"Syrians are Hard-Working"}

The Syrian men and women participants emphasized their strong belief in "working hard," a key factor that was perceived as shaping and defining the Syrian people's identity. As this male participant, Adnan, emphasized:

I don't want to praise Syrian people, but it is well known that Syrians are hardworking people who have different skills. And you also know that Syrians have worked in Jordan, Egypt, and other parts of the world and proved that they can do almost anything. (Focus group, January 2, 2017)

The concept of what constituted being "hard-working" was defined by the participants in accordance with carefully demarcated gender lines. Back home, the men were proud to be husbands and fathers who were able to provide for their families, often working two or three jobs to ensure economic stability. Some participants withdrew from formal education in their early teens to pursue informal apprenticeships in a trade (electrician, sewing machine repair, mechanic, construction, etc.), while one went on to university and became a pharmacist. All of the men proclaimed that they were experts in a certain field(s) and had previously held multiple jobs in different countries to financially support their families. For example, Khaled talked about how he has the ability and experience to take one of four different occupations:

I know how to build and paint houses, I know the basics of working as an electrician, I'm a driver and a farmer ... I'm not saying that the skills that I just mentioned are some kind of hobby, I have mastered them all. (Focus group, July 6, 2017)

The women first and foremost positioned themselves as Muslim wives and mothers, but also conceived of themselves as "hard-working," assuming multiple roles to care for their children while contributing to the family's income. Apart from one university-educated participant who had worked as a teacher, these women all worked from home doing farming, sewing, growing Journal of Contemporary Issues in Education, 2019, 14(1), pp. 71-88. 
vegetables to sell, or operating a home-based child care program. As Hiyam stressed, each of her family members had a role in supporting their wellbeing:

Every member of the family would have something to do. We would sometimes rent a piece of land and every one of us would have an assigned duty that they need to take care of... We would all be involved in planting and harvesting different crops. We would never live with the idea of not having a job. (Focus group, July 8, 2017)

As will be discussed, within the new home country, these identity positions were threatened by language barriers which hindered the participants from finding employment and navigating daily life in Regina.

\section{Language and Maintaining an Identity as a "Worker"}

In the Canadian context, the men and women approached their English classes somewhat differently. The men were primarily concerned with securing employment and they were not convinced that their language classes were a means of doing so, while for the women employment was a significant, but secondary, concern as they still needed to care for their children. As Dana amplified, employment would allow her to "help my husband with some of these life expenses" (Focus Group, December 28, 2016). The men's urgency to find employment seemed to be fueled by this long history of "hard work" and being the primary providers, values that were highly regarded and formed and shaped their identities. All of our male participants attended job fairs and workshops organized by local settlement agencies or worked as volunteers in the trades in hope of securing suitable employment. While their skills were highly appreciated by their supervisors, they were told that English language proficiency was a prerequisite for employment as Adnan explained: "Employers are looking for people who hold at least level 5 (Canadian Language Benchmarks) in English" (Focus Group, January 2, 2017). Other barriers included age, credential recognition, health concerns.

In their English language classes, many of the men perceived that they were not going to accrue the "right" linguistic capital needed to secure employment. As one male participant, Radi, explained, they desired to learn more of the conversational or "practical" English:

I have to be honest and say that the language classes that we go to aren't helping us. We go to class and learn a couple of words and then go back home for the rest of the day. There isn't any kind of exposure to the real English that we need in order to survive in this new place. (Focus group, January 2, 2017)

Another male participant likewise equated knowledge of conversational English with survival. Ammar asserted: "We are not taught the actual language - the street language - that we need to survive" (Focus group, January 2, 2017). Thus, a particular form of linguistic capital is closely associated with the more immediate concern of economic survival in their minds.

The women were similarly highly motivated to learn in order to fulfill their hopes for eventual employment in the Canadian context. As Samira declared:

It's all in God's hands and I always thank him for his help. The thing is that we have a goal that we are determined to accomplish. Now, I think I would do whatever it takes to achieve these goals. (Focus group, July 8, 2017)

Women who hoped to find employment outside of the home found that, similar to the men, language was a barrier. Rawan explained: "All we need is for them to help us find work. No one is hiring us because of the language. They [employers] require that we finish a certain level in 
English" (Focus Group, December 28, 2016). Consistent with the men's views, they contended that they should be able to transfer their job skills from back home, but it became clear that options were limited without English, as Ibtisam described:

We wouldn't say that working in cleaning is shameful nor that we wouldn't want to work in such a thing, it's just that we came here with different skills, why don't they help us improve these skills and find us jobs that fit within these skills? (Focus group, December 28, 2016)

Given their goal of becoming employed and the perception that language classes would not aid them in achieving that goal, many of the men contended that they felt they were better served learning English on the job within their chosen occupations. These opinions were formed, in part, by stories of newcomers who had arrived before them and completed their language training. As Ghazi lamented: "we look at those who came before who haven't found a job yet and think 'what's the use (of studying)"” (Focus Group, July 7, 2017). Since they had already constructed identities as resourceful and skilled workers, they believed the need for formalized language instruction was eliminated. Two male participants, Haitham and Nader described the situation:

You know what, we don't need the language. All we need is that they help us find jobs. Through working, we will learn everything. We will be able to both speak the language and also learn a certain profession at the same time. I have been an electrician for almost 20 years, do you want me to work, at this age, as a cleaner? Is that logical? (Focus group, January 2, 2017)

It would take me a short while to learn all of the words and terms used within a certain profession. I don't have to be fluent to get a job done. And we are not dumb to think we will not be able to learn such terms (laughter)... (Focus group, January 2, 2017)

That is, they sought to mobilize capital amassed through their work experience back home as a pathway to acquiring the necessary linguistic and social capital within Canadian society.

\section{Language and Identity as a Parent}

All of the female and a few male participants stressed that their language classes were also not relevant to their needs and responsibilities as parents. The women, in particular, asserted that the language training providers' goals for the English classes diverged from their own and thus did not give them the "right" English to function in their everyday lives as wives, mothers, and caregivers. For instance, Salman explained that the formal grammar lessons they were receiving did not have much utility for them:

We need to learn certain skills that would help us communicate with other people. At our language school, they sometimes teach us things like, he, she, it, these are things that we don't actually make use of. But if they would teach us how to speak in different situations, like, at the mall, at the hospital, that would be much more beneficial. (Focus group, December 28, 2016)

Similarly, another woman, Manar, complained: "What are we supposed to do with the papers [worksheets] that our teacher gives us! We want to learn how to speak the language" (Focus Group, July 8, 2017). They hoped for more "conversation practice" as they felt they "benefitted a lot" from it (Focus Group, July 8, 2017). Their inability to transfer their classroom learning to ease their daily living tasks led to frustration over their lack of progress as situations arose dayto-day, as Dana articulated: 
In terms of language, they are helping us learn English, but our English isn't developing. I've been studying for about 15 months but I'm still unable to speak properly, I can only speak the basics. (Focus Group, December 28, 2016)

Living in the new context had contributed to a concomitant shift in traditional gender roles, and some of the men participated in more of the domestic work. One Syrian father, Ibrahim, recalled how he got lost three times while trying to buy groceries for his family because he wasn't able to read English, nor did he have the confidence to ask for directions to get back home:

I got on the bus to Walmart and once I finished my shopping, I tried to go back home by taking the same bus. I didn't know where to wait for the bus nor did I know when the bus will come. I started crying... I tried going back into the store... I tried to get him [an employee] to understand...I didn't know what to do. (Focus Group, January 2, 2017) Another man, Ghazi, talked about how without the power to speak and be understood, he could not effectively demand better treatment, which led to emotional repercussions. Ghazi informed us that he had to deal with application issues related to government-subsidized housing:

I went to the housing authority to ask about my application since a lot of the people who signed up after me for these houses have received a place, but I didn't have the language skills to communicate with them. So, I asked a friend who speaks English to come with me to the Housing Authority and help me understand what's going on. (Focus Group, January 2, 2017)

The participants asserted that in order to effectively care for their families, they needed a particular form of "practical" English that they did not believe they were learning.

\section{Language and Muslim Identity}

While the men did not articulate tensions around being Muslim in relation to their language classes, the women did not find the structure of their classes to be congruent with their faith since they were expected to study alongside men. As Ibtisam explained:

Because of our culture and religion that we are not permitted to sit with foreign men.

Even when we are in school our teacher could tell how uncomfortable we are sitting next to men. Unfortunately, we are forced to be with men, but that doesn't mean we like it.

(Focus Group, December 28, 2016)

Whereas men of the same faith understood the strictures of their religion, the diversity of the class composition necessitated contact with men that made them feel ill at ease. Their desire to learn English superseded their own culturally-constructed beliefs and values about what constituted a "good" Muslim woman. Still, Manar expressed the wish for more culturallyconsonant instruction: "With all due respect, if I was to practice speaking English with a Canadian lady, I would benefit from talking to her more than I would from our language school" (Focus Group, July 8, 2017).

\section{Shifts in Identity}

These refugees did recognize that learning English was one of the most significant factors for succeeding in their receiving society, however, their views of how and what they should be learning was at odds with the classroom-based, prescribed program in their language training classes. Their multiple identities as hard-working, employed, independent, Muslim mothers or fathers, and wives or husbands developed in Syria were gradually eroded or altered by the realities they experienced in Canada. The identity of being a "hard worker" was being threatened or even erased by the inability to gain employment and ongoing dependence on Journal of Contemporary Issues in Education, 2019, 14(1), pp. 71-88. 
government financial support, which led to depression and loss of status. For instance, male participant Zaid noted:

There are feelings of depression, but the only reason that is helping us cope with our situation is that we are receiving a certain amount of income from the government. We don't worry about buying things for ourselves or our children, paying the rent, the bills, and gas for our cars, we can afford it. This is why we are obeying to what they have offered us. Eventually, we would definitely want to work. We've applied for jobs through the [settlement agency], but we haven't had any luck yet due to our language abilities. They [employers] ask us to finish at least level 5! (Focus Group, July 6, 2017) This discussion between two men, Rateb and Malik, underscored their anxieties around studying instead of working:

Malik: "Yes. That's true, we're getting lazy and overweight here."

Rateb: "Just staying at home with nothing to do is terrible. We don't have the opportunity to move our bodies as we used to" (Focus group, July 7, 2017). Ahmad, similarly expressed his frustration at his state of unemployment: "I do understand that learning English is very important, but there must be another way for us to work instead of staying home all day" (Focus group, January 2, 2017). The women infantilized their husbands, comparing them to schoolchildren. Khawla, commented: "We want them to work instead of staying at home all day. They go to school like little children and come back to do nothing." Compelling the men to attend English classes instead of facilitating their entry into the Canadian workforce shattered traditional gender roles which positioned men as the primary breadwinners working outside the home.

Our participants also described how their lack of English language skills affected their ability to communicate and the feelings of frustration, shame, and anxiety that accompanied such incapability. They recognized that building social networks with people outside their community was an important factor in many aspects of their resettlement, especially learning English. For many of our participants, building social networks with Canadians started with the 'family friends' who volunteered to help Syrian families settle in at the time of their arrival to Regina and helped them. Rukayah recalled her individual sense of linguistic isolation when being unable to join a conversation with her 'family friends,' stating:

When our family friends visit us, my husband engages with them in different conversations and I just stand there not understanding a word of what they are talking about. It's becoming very embarrassing for me. (Focus group, July 8, 2017)

One of the men, Jalal, echoed this sentiment: "In my opinion, even when we approach someone who speaks fluent English and that person sees that your English is terrible, he would think that you're insane or they would simply walk away" (Focus group, January 2, 2017). Ammar added that friendship with a Canadian would allow them to develop their English skills and "solve your own problems and get things done without depending on others" (Focus group, January 2, 2017). The notion of dependence was difficult for the participants to come to terms with and they perceived English as central to gaining resources, becoming independent, and forming new social networks and, correspondingly, social capital.

The women stated that they felt less pressured and discouraged than the men because their primary focus was their child-rearing responsibilities. Some of them even found ways to mobilize their linguistic capital from "back home" in the new context in ways the men could not Journal of Contemporary Issues in Education, 2019, 14(1), pp. 71-88. 
by working from the home and within the Arabic-speaking community. Several of the women had started home businesses selling Syrian cooking and hoped to eventually run restaurants. One woman who was a teacher back home had secured employment teaching Arabic and the Quran at a local mosque. The mosque and Islamic Association helped participants maintain their cultural identities and form new social networks and connections, acting as an extension of their cultural (religious teachings and practices) and perhaps social capital (relations with others) (Modood, 2004). However, expansion into the mainstream dominant society proved daunting due to their English language abilities. Ironically, they perceived that conversational English was the most critical form of linguistic capital in terms of meeting their employment and daily living needs, it was written English in the form of regulations and paperwork that proved to be a barrier to expansion. Nawal explained the obstacles they faced:

For me, I would like my English language to become better than what it is now. We already completed the [cookery] course and wrote our resumes. We also registered our company [home cooking] but no one has informed us yet about what are we supposed to do next. We need the experience. You know, a newcomer obviously needs someone to help them learn. (Focus group, December 28, 2016)

In the case of the women, whose identities were derived from being mothers and caregivers, they predominantly gravitated toward domestic employment options which were less reliant on English language ability as they catered to the Syrian community.

\section{Discussion}

The participants' discussions confirm what has been noted in previous research; that lack of work contributes to newcomers' vulnerability to conditions of social exclusion (Wilkinson et al., 2016), which may lead them to experience depression, fear, anxiety, and stress (Bryan \& Denov, 2011; Galabuzi, 2004; 2010). Our participants overwhelmingly sought to re-establish their identity constructions from back home in the new context; especially these identities as "hard workers," providers, and carers. "Working hard" and being employed were seen to bestow legitimacy or symbolic capital that nurtured the participants' desire to become independent and self-supporting. The participants' habitus or dispositions to act and speak in particular ways were intertwined with these different identity positionings. In the participants' minds, the occupational and daily living skills they had cultivated back home were transnational resources or capital they presumed could be transferred to, and recognized within, the Canadian context if only they were given the opportunity to volunteer or work. Indeed, they had been provided reassurance by prospective employers that they could do so, although other studies suggest that other unobserved structural factors related to social and human capital could function to impede their entry into the labour force (Raza, Beaujot \& Woldemichael, 2013). As Duran (2016) has noted, such transnational capital can create affordances for newcomers to participate in professional activities in multiple countries. Contrary to other studies (e.g. De Costa, 2010; Peters, 2008), our participants did not view English as a pathway to finding a "good job," but rather affirmed that their employment skills would guarantee them work, then the English would follow. Yet, they were discouraged to find that migration to a new field, a place where their linguistic capital had lost its value in navigating the workplace and daily life emphasized the necessity of transforming and re-structuring their habitus in this new social world. While newcomers who have been in Canada a little longer identify additional barriers to employment and economic integration such as discrimination (accent), racism, and sexism (Kikulwe, Massing, Halabuza, Giesbrecht, \& Journal of Contemporary Issues in Education, 2019, 14(1), pp. 71-88. 
Ghadi, 2017; Raza, Beaujot, \& Woldemichael, 2013), these Syrian participants believed that their English language skills were the sole barrier to employment. This finding contradicts the existing literature such as George and Chaze (2014) who argue that the inability to transition into one's field of work should not be perceived by newcomers as a personal failure but rather as the result of structural barriers that hinder them in accessing jobs in their line of work. We found no evidence of the "Muslim employment gap" cited in other studies (eg. Connor \& Koenig, 2015 Lindemann \& Stolz, 2018), but further research is needed to understand if this is the case once they have been in Canada for more time. Echoing the findings of Austin and Este (2001), maintaining existing identities around being "hardworking" providers proved to be problematic in view of this loss as they could not activate their diverse resources and social networks to secure employment without English language skills. This might also be attributed to Syrian men's sense of their role as men and primary breadwinners. Being unemployed would threaten how a man defines himself as the financial provider for the rest of the family hence he might assume the role of protecting, and even controlling, other family members (El Feki, Heilman \& Barker, 2017). However, while most of our male participants indicated that their main role was to find and maintain adequate employment in order to provide for their family, they were supportive of their wives assisting in this regard. It was the women, rather, that constructed their husbands as 'children' for attending school instead of working and providing for the family.

Existing studies of language capital and its relationship to language learning indicate that learning the host language is critical for refugees because it facilitates their integration and decreases their sense of insecurity and alienation (Hou \& Beiser, 2006; Dustmann \& Fabbri, 2003). Learning English not only becomes a means of communicating with others or a tool for building social relationships, but also an entry point into a new way of life that could reflect a new sense of identity and a way of positioning oneself within the larger community (Peirce, 1995). Our study participants came to understand that learning English was a necessary source of learning to live in a new context and attaining social power. In this regard, migration scholars have pointed out that power relations are embedded in linguistic interactions (Putnam, 2007; Norton \& Toohey, 2011). Similar to the results of various studies (Baer, 2008; Makwarimba et al., 2013), our participants experienced frustration in their everyday interactions with others and felt disempowered. While the participants ascribed value to learning English to navigate their everyday lives, they were dubious that their classes would aid them in achieving their goals.

In this study, the participants' quest to "fit in" in the Canadian context was conjoined with informal language learning - in the workplace or in social situations with Canadian English first language speakers. They maintained that their English classes did not equip them with the "right" English to secure employment - the specialized discourse used in each occupation (Beiser \& Hou, 2000). In all but a few cases, the participants had primarily been educated more informally back home; that is, through apprenticeships whereby experts guided them in mastering occupations rather than through classroom study. They similarly situated language learning within this apprenticeship model (Lave \& Wenger, 1991; Rogoff, 1990), asserting that expert English speakers could expose them to this oral, conversational English on the job, allowing them to maintain the habitus or dispositions associated with speaking from within the occupation. For these men, then, their previous experiences of the apprenticeship model of informal education likely influenced their beliefs that they could learn English while working, thus leading them to believe that formal English classes were a waste of time. Native speakers 
working in these occupations were thus positioned as the experts because the job-specific communicative skills they were able to impart were a potential source of linguistic, thus by extension economic, capital for the participants (Goldstein, 2007). In contrast, the type of English that their classroom instructors delivered was seen to lack value, emphasizing reading and writing skills that they felt were dissonant with their own lives even though this was not actually the case for the women who hoped to expand their home businesses. This same notion held true in terms of learning practical English for daily living as the women emphasized that they wanted to learn conversational English from "Canadian ladies." Therefore, specific aspects or forms of English were viewed as higher status linguistic capital (Morrison \& Liu, 2000), as well as a means of achieving symbolic capital in the Canadian occupational context (Bourdieu, 1986).

Contrary to other studies of refugee women which problematize the patriarchal underpinnings of prescribed gender roles (Akua-Sakyiwah, 2016), such demarcations did not necessarily impose symbolic violence on these women, but rather seemed to have mitigated some of their anxieties around finding paid employment. As mothers and wives, they required English to care for their families - for shopping, doctor's appointments, and other tasks - thus they were very motivated learners. However, they primarily spoke of their own employment in terms of their hopes and goals rather than as a necessity. The culturally defined and socially constructed expectations around working in the home allowed some of them to leverage their transnational linguistic and social capital and start home businesses to serve their community. In this way, they could actively work toward securing the family's independence from the government and achieve symbolic power. However, their English language skills imposed limits on their expansion beyond the Arabic-speaking community and hindered them in constructing bridging social capital acquired through sustained contact with newcomers from other cultural communities.

\section{Implications}

Current scholarship suggests that the inability to develop English language skills constructs learners as the educational problem, thus the onus of solving this dilemma rests with them (Burton, 2016). For the women, being Muslim contributed to feelings of discomfort in their language classes because they were compelled to study alongside men who did not share their religious values and beliefs. The tensions inherent in learning a new way of being and acting in this context while adhering to the strictures in their religion was challenging. It should be noted that none of our participants identified instances of racism or Islamophobia and, based on the findings in our larger study, we theorize that this might be due to their status as newcomers whose English language skills inhibited their understanding of nuances in communication and their ability to develop social relationships with Canadians. For their part, the men sought to work, gain their independence, and repay the government, but did not believe their language classes would support them in doing so. These examples point to the importance of instructors and program designers taking language learners' backgrounds into account when developing a curriculum and methodology for a given social context of instruction. Individualizing language learning problems and the negative attributes attached to those who lack English skills can heighten the challenges experienced by newcomers seeking to enter the labour market to (re)build social and economic capital. Bridging programs or workplace embedded programs which tailor language instruction to specific occupations would be well-received by these Journal of Contemporary Issues in Education, 2019, 14(1), pp. 71-88. 
participants. Some also suggested mentorships wherein more established members of their linguistic community could act as language brokers in the field, thus enabling them to work in their chosen professions while learning English. Increased sensitivity to newcomers' occupational language needs should also be intertwined with a re-visioning of current credential evaluation and recognition mechanisms. The development of programs which incentivize employers and professional bodies to find ways to diversify their workforce and provide on the job language instruction is an area needing further study. Such increased sensitivity to newcomers' language needs should also dovetail with the desperate need for effective credential evaluation and professional upgrading programs. In the end, language learning is a socially embodied process that not only benefits individual refugees but also the fields they seek to enter.

\section{References}

Adamuti-Trache, M. (2012). Language acquisition among adult immigrants in Canada: The effect of premigration language capital. Adult Education Quarterly, 63(2), 103-126. http://dx.doi.org/10.1177/0741713612442804

Akua-Sakyiwah, B. (2016). Education as cultural capital and its effect on the transitional issues faced by migrant women in the diaspora. International Migration and Integration, 17, 1125-1142. https://doi.org/10.1007/s12134-015-0455-8

Alshabibi, N. (2018). Female Saudi dependent students and language learning investment and resistance: A case study of four female Muslim Saudi students in the US (Order No. 10816254). Available from ProQuest Dissertations \& Theses Global. (2114885633). Retrieved from https://login.libproxy.uregina.ca:8443/login?url=https://search-proquestcom.libproxy.uregina.ca/docview/2114885633?accountid=13480).

Austin, C. \& Este, C. (2001). The working experiences of underemployed immigrant and refugee men. Canadian Social Work Review, 18(2), 213-229.

Baer, D. (2008). Community context and civic participation in immigrant communities: A multilevel Study of 137 Canadian communities. Metropolis British Columbia Working Paper Series, No. 08-03.

Beiser, M., \& Hou, F. (2000). Gender differences in language acquisition and employment: Consequences among Southeast Asian refugees in Canada. Canadian Public Policy / Analyse De Politiques, 26(3), 311-330. https://doi.org/10.2307/3552403

Berry, R. S., \& Williams, M. (2004). In at the deep end: Difficulties experienced by Hong Kong Chinese ESL learners at an independent school in the United Kingdom. Journal of Language and Social Psychology, 23(1), 118-34. https://doi.org/10.1177/0261927X03260810

Bourdieu, P. (1977). Outline of a theory of practice. Cambridge, UK: Cambridge University Press. https://doi.org/10.1017/CBO9780511812507

Bourdieu, P. (1984). Distinction: A social critique of the judgment of taste. Cambridge, MA: Harvard University Press.

Bourdieu, P. (1986). The forms of capital. In J. Richardson (Ed.), Handbook of theory and research for the sociology of education (pp. 241-258). New York, NY: Greenwood.

Bourdieu, P. (1990). The logic of practice. Stanford, CA: Stanford University Press.

Bourdieu, P. (1991). Language and symbolic power. Cambridge, MA: Harvard University Press.

Bourdieu, P. (1997). The forms of capital. In A. H. Halsey, H. Lauder, \& P. Brown (Eds.), Education: Culture, economy, society (pp. 46-58). Oxford: Oxford University Press.

Journal of Contemporary Issues in Education, 2019, 14(1), pp. 71-88. 
Bourdieu P. (2000). The social structures of the economy. New York, NY: Polity.

Bourdieu, P. (2001). Masculine domination. Cambridge, UK: Polity Press.

Bourdieu, P., \& Wacquant, J. (1992). An invitation to reflexive sociology. Chicago, IL: University of Chicago Press.

Boyd, M., \& Cao, X. (2009). Immigrant language proficiency, earnings, and language policies. Canadian Studies in Population, 36(1-2), 63-86. https://doi.org/10.25336/P6NP62

Bryan, C., \& Denov, M. (2011). Separated refugee children in Canada: The construction of risk identity. Journal of Immigrant \& Refugee Studies, 9(3), 242-266. https://doi.org/10.1080/15562948.2011.592806

Bucholtz, M. (1999). Why be normal? Language and identity practices in a community of nerd girls. Language in Society, 28(2), 203-223. https://doi.org/10.1017/S0047404599002043

Burton, J. (2016). Be(come)ing an English speaker: Positioning of South Korean students in a Canadian university. (Unpublished master's thesis). University of Regina, Regina.

Citizenship and Immigration Canada (CIC). (2016). Welcome refugees: Security and health screening. The government of Canada. Ottawa, ON: CIC. Retrieved from: http://www.cic.gc.ca/english/refugees/welcome/overview/security.asp

Citizenship and Immigration Canada (CIC). (2017). Welcome refugees: Key figures. Retrieved from http://www.cic.gc.ca/english/refugees/welcome/milestones.asp

Connor, P., \& Koenig, M. (2015). Explaining the Muslim employment gap in Western Europe: Individual-level effects and ethno-religious penalties. Social Science Research, 49, 191201. https://doi.org/10.1016/j.ssresearch.2014.08.001

De Costa, P.I. (2010). Language ideologies and standard English language policy in Singapore: Responses of a 'designer immigrant' student. Language Policy, 9, 217-239. https://doi.org/10.1007/s10993-010-9176-1

De Clercq, D., \& Voronov, M. (2009). The role of domination in newcomers' legitimation as entrepreneurs. Organization, 16(6), 799-827. https://doi.org/10.1177/1350508409337580

Duran, C.S. (2016). "I Want to Do Things with Languages": A male Karenni refugee's reconstructing multilingual capital. Journal of Language, Identity \& Education, 15(4), 216-229. https://doi.org/10.1080/15348458.2016.1194208

Dustmann, C., \& Fabbri, F. (2003). Language proficiency and labor market performance of immigrants in the UK. The Economic Journal, 113(489), 695-717. https://doi.org/10.1111/1468-0297.t01-1-00151

Eakin, P. J. (2008). Living autobiographically: How we create identity in narrative. Ithaca, N.Y: Cornell University Press.

Eckert, P., \& McConnell-Ginet, S. (2003). Language and gender. Cambridge, UK: Cambridge University Press. https://doi.org/10.1017/CBO9780511791147

El Feki, S., Heilman, B. \& Barker, G. (Eds). (2017). Understanding masculinities: Results from the international men and gender equality survey (IMAGES) - Middle East and North Africa: Executive summary. Cairo and Washington, DC: UN Women and PromundoUS.

Galabuzi, G.-E. (2004). Social exclusion. In D. Raphael (Ed.), Social determinants of health: Canadian perspectives (pp. 235-250). Toronto, ON: Canadian Scholars' Press.

Galabuzi, G.-E. (2010). Measuring racial discrimination in Canada: A call for content and more inclusive approaches. Canadian Journal for Social Research, 3(2), 24-44.

Gemme, B. (2009). The outside within: Heteronomy in the training of forest researchers (Unpublished doctoral dissertation). The University of British Columbia, BC: Canada.

Journal of Contemporary Issues in Education, 2019, 14(1), pp. 71-88. 
Retrieved from

https://circle.ubc.ca/bitstream/handle/2429/11993/ubc_2009_fall_gemme_brigitte.pdf

George, U., \& Chaze, F. (2009). Tell me what I need to know: South Asian women, social capital and settlement. The Journal of International Migration and Integration (JIMI), 10(3), 265-282. https://doi.org/10.1007/s12134-009-0102-3

George, U., \& Chaze, F. (2014). Discrimination at work: Comparing the experiences of foreigntrained and locally-trained engineers in Canada. Canadian Ethnic Studies, 46(1), 1-21. https://doi.org/10.1353/ces.2014.0002

Gerhards, J. (2012). From Babel to Brussels. European integration and the importance of transnational linguistic capital. Berlin Studies on the Sociology of Europe (BSSE) No. 28. Berlin: Freie Universität Berlin.

Goldstein, T. (2007). The capital of "attentive silence" and its impact on English language and literacy education. In J. Albright \& A. Luke (Eds.), Pierre Bourdieu and literacy education (pp. 209-232). New York, NY: Routledge.

Gotseva, M. (2015). Some factors which may affect the attainment of implicit and explicit knowledge in learning English as a second/foreign language. English Studies at NBU, $1(2), 85-100$.

Hall, J. K. (2012). Teaching and researching language and culture. Harlow, England: Longman.

Hesse-Biber, S., \& Leavy, P. (2006). Focus group interviews. The practice of qualitative research. Thousand Oaks, CA: Sage.

Hilgers, M., \& Mangez, E. (2015). Bourdieu's theory of social fields: Concepts and applications. London: Routledge.

Holmes, J. (1997). Women, language and identity. Journal of Sociolinguistics, 1(2), 195-223. https://doi.org/10.1111/1467-9481.00012

Hou, F., \& Beiser, M. (2006). Learning the language of a new country: A ten-year study of English acquisition by South-East Asian refugees in Canada. International Migration, 44(1), 135-165. https://doi.org/10.1111/j.1468-2435.2006.00358.x

Jenkins, R. (2002). Pierre Bourdieu. London: Routledge.

Kikulwe, D., Massing, C., Halabuza, D., Giesbrecht, C., \& Ghadi, N. (2017). Barriers to employment, education, and child care experienced by newcomers to Regina. Research report submitted to Immigrants, Refugees, and Citizenship Canada by the Regina Region Local Immigration Partnership.

Krais, B. (2006). Gender, sociological theory and Bourdieu's sociology of practice. Theory, Culture \& Society, 23(6), 119-134. https://doi.org/10.1177/0263276406069778

Kunz, J. (2003). Social capital: A key dimension of immigrant integration. Canadian Issues, April 2003, 33-34.

Lave, J. \& Wenger, E. (1991). Situated learning: Legitimate peripheral participation. New York, NY: Cambridge University Press. https://doi.org/10.1017/CBO9780511815355

Lichtenstein, G., Puma, J., Engelman, A., \& Miller, M. (2016). The Refugee integration survey \& evaluation: Year 5 Report. Technical report by Quality Evaluation Designs. Denver, CO: Colorado Office of Economic Security. Retrieved from:

http://qualityevaluationdesigns.com/published-reports/refugee-integration-surveyevaluation-rise $\% \mathrm{EF} \% \mathrm{BB} \% \mathrm{BF} /$

Lindemann, A., \& Stolz, J. (2018) The Muslim employment gap, human capital, and ethnoreligious penalties: Evidence from Switzerland. Social Inclusion, 6(2), 151-161. 
https://doi.org/10.17645/si.v6i2.1395

Makwarimba, E., Stewart, M., Simich, L., Makumbe, K., Shizha, E., \& Anderson, S. (2013).

Sudanese and Somali refugees in Canada: Social support needs and

preferences. International Migration, 51(5), 106-119.

https://doi.org/10.1111/imig.12116

Modood, T. (2004). Capital, ethnic identity, and educational qualifications. Cultural Trends

13(2), 87-105. https://doi.org/10.1080/0954896042000267170

Morgan, B. (2007). Poststructuralism and applied linguistics: Complementary approaches to identity and culture in ELT. In J. Cummins \& C. Davison (Eds.), International handbook of English language teaching (pp. 1033-1052). New York, NY: Springer.

https://doi.org/10.1007/978-0-387-46301-8_69

Morrice, L. (2012). Learning and refugees: Recognizing the darker side of transformative learning. Adult Education Quarterly, 63(3), 251-271. https://doi.org/10.1177/0741713612465467

Morrison, K., \& Lui, I. (2000). Ideology, linguistic capital and the medium of instruction in Hong Kong. Journal of Multilingual and Multicultural Development, 21(6), 471-486. https://doi.org/10.1080/01434630008666418

Murray, D. (1998). Ebonics: A case study in language, power, and pedagogy. TESOL Quarterly 32(1), 144-46. https://doi.org/10.2307/3587912

Norton, B. (1995). Social identity, investment, and language learning. TESOL Quarterly, 29(1), 9-31. https://doi.org/10.2307/3587803

Norton, B. (2000). Identity and language learning. London: Longman.

Norton, B. (2006). Identity as a sociocultural construct in second language education. In K. Cadman, \& K. O'Regan (Eds.), Tales out of school: Identity and English language teaching (pp. 22-33). Canberra: Australian Council of TESOL Associations.

Norton, B., \& Toohey, K. (2011). Identity, language learning, and social change. Language Teaching, 44(4), 412-446. https://doi.org/10.1017/S0261444811000309

Nunan, D., \& Choi, J. (2010). Language and culture: Reflective narratives and the emergence of identity. New York, NY: Routledge.

Ostrovsky, Y. (2008). Earnings inequality and earnings instability of immigrants in Canada. Statistics Canada Catalogue no. 11F0019M - No. 309. Retrieved from http://www.statcan.gc.ca/pub/11 f0019m/11f0019m2008309-eng.pdf

Peirce, B. (1995). Social identity, investment, and language learning. TESOL Quarterly, 29(1), 931. https://doi.org/10.2307/3587803

Perrin, R. L., \& Dunn, K. (2007). Tracking the settlement of North African immigrants: speculations on the social and cultural impacts of a newly arrived immigrant group. Australian Geographer, 38(2), 253-273. https://doi.org/10.1080/00049180701395355

Peters, N. (2008). Offshore visibly different refugees: Employment status as it relates to their English language proficiency. International Journal of Diversity in Organisations, Communities \& Nations, 7(6), 39-57. https://doi.org/10.18848/14479532/CGP/v07i06/39487

Plante, J. (2011). Integration of internationally-educated immigrants into the Canadian labour market: Determinants of success. Statistics Canada Catalogue no. 81-595-M - No. 094. Retrieved from http:/www.statcan.gc.ca/pub/81-595-m/81-595-m2011094-eng.pdf

Journal of Contemporary Issues in Education, 2019, 14(1), pp. 71-88. 
Putnam, R. (2007). Diversity and community in the twenty-first century. Scandinavian Political Studies, 30(2), 137-174. https://doi.org/10.1111/j.1467-9477.2007.00176.x

Raza, M., Beaujot, R., \& Woldemicael, G. (2013). Social capital and economic integration of visible minority immigrants in Canada. Journal of International Migration and Integration 14(2), 263-285.

Rogoff, B. (1990). Apprenticeship in thinking: Cognitive development in social context. New York, NY: Oxford University Press.

Rudenko, M. (2012). Canadian experience' and other barriers to immigrants' labour market integration: Qualitative evidence of newcomers from the former Soviet Union (Master's thesis). Retrieved from Theses and dissertations. (Publication number 1676).

Salö, L. (2017). The sociolinguistics of academic publishing: Language and the practices of homo academics. New York, NY: Springer. https://doi.org/10.1007/978-3-319-58940-4

Sanders, J., Nee, V., \& Sernau, S. (2002). Asian immigrants' reliance on social ties in a multiethnic labor market. Social Forces, 81(1), 281-314. https://doi.org/10.1353/sof.2002.0058

Spradley, J. P. (1979). The ethnographic interview. New York: Holt, Rinehart and Winston.

Sutherland, S., Wheller, M., \& Conrad, D. (2008). Building competency-based portfolios for immigrants. In L. Servage (Ed.), Proceedings of the 2008 Work and Learning Network Conference (pp. 111-117). Edmonton: University of Alberta.

Weiner, N. (2008). Breaking down barriers to labour market integration of newcomers in Toronto. IRPP Choices, 14(10), 1-37.

Wibeck, V., Dahlgren, M. A., \& Öberg, G. (2007). Learning in focus groups: An analytical dimension for enhancing focus group research. Qualitative Research, 7(2), 249-267. http://dx.doi.org/10.1177/1468794107076023

Wilkinson, L., Bhattacharyya, P., Bucklaschuk, J., Shen, J., Chowdhury, I., \& Edkins, T. (2016). Understanding job status decline among newcomers to Canada. Canadian Ethnic Studies, 48(3), 5-26. http://dx.doi.org/10.1353/ces.2016.0023

Journal of Contemporary Issues in Education, 2019, 14(1), pp. 71-88. 